\title{
Supplementary Studies of American Chrysobalanaceae 3
}

\author{
Ghillean T. Prance (*)
}

\begin{abstract}
.
This paper is the third in a series of additio. nal publications on the plant family Chrysobala naceae. The new species Couepia marlenei Prance, and subspecies Licania octandra (Hoffmgg. ex Roem. \& Schult.) Kuntze subsp. grandifolia are described. Notes on additional collections of five other species are given. Two of these were previously known only from the types. Licania affnis Fritsch, a species well-known in the Guianas and eastern Amazonia is shown to have a disjunct distribution, since it has now been collected in $\mathrm{Pa}$. nama.
\end{abstract}

\section{INTRODUCTION}

Since my monograph of American Chry. sobalanaceae (Prance 1972), continued field activity has resulted in various important additions (Prance 1973, 1974). This paper adds another new species of Couepia collected recently on the new highway between Manaus and Porto Velho, a new subspecies of Licania and a few important additional collections of, or range extensions to, another five species. Since the last paper nearly 500 additional exsiccatae have been studied, and only the most important are cited here. It is intended to give a more complete list at a later date.

\section{Couepia marlenei Prance, sp. nov.}

Arbor parva ad $8 \mathrm{~m}$ alta, ramulis juvenilibus sparse puberulis mox glabris. Stipulae parvae, $1 \mathrm{~mm}$ longae, triangulares. Folia alternata, petiolata; petiolo $4-7 \mathrm{~mm}$ longo, sparse puberulo vel glabro, supra canaliculato; laminae oblongo-lanceclatae, $5-8 \mathrm{~cm}$ longae, $1.5-2.4 \mathrm{~cm}$ latae, apice in acuminem $5-15 \mathrm{~mm}$ longum con- tractae, basi subcuneatae, cum glandibus duobus ad laminae cum petiolo junctarum insertis, supra glabrae, subtus sparse et breviter araneoso-pubescentes; costa media supra glabra, prominula, subtus prominenti; nervis secundariis 7-10 jugis subtus prominentibus. Flores in racemis terminalibus dispositi, rachi puberuli. Bracteae parvae caducae. Receptaculum cylindricum, basim versus inflatum, $15-18 \mathrm{~mm}$ longum, extus sparsissime puberulum, intus prope faucem infra stamina dense pilosum, basim versus glabrum. Calycis-lobi 5 , rotundati, extus sparse puberuli, marginibus ciliati. Petala 5, alba, marginibus ciliatis. Stamina multa, in orbem completum disposita. Ovarium ad faucem receptaculi insertum, dense pilosum. Stylus e basi ovarii ortus, ad medium pilosus. Fructus mihi ignotus.

TYPE - Marlene F. da Silva e pessoal da Botânica 822, Brasil, Amazonas, Estrada Manaus-Porto Velho entre Rios Castanho e Tupana. Arvoreta de $4 \mathrm{~m}$ de altura, na mata de terra firme, argilosa, com flores. Julho de 1972 (INPA 36913).

\section{ADDITIONAL MATERIAL}

Brasil, Amazonas: Estrada Manaus-Porto Velho, Km. 113, Marlene F. da Silva et al 267 com flores, julho de 1972 (INPA 36358); Estrada Manaus-Porto Velho entre Rios Castanho e Araça, Marlene F. da Silva et al 490, esteril (INPA 36581).

Couepia marlenei is most closely related to $C$. williamsii Macbr., and differs in the much smaller leaves with few secondary nerves, the sparse pubescence and more reticulate venation of the leaf undersurface, and the (") - Instituto Nacional de Pesquisas da Amazônia, and B. A. Krukoff Curator of Amazonian Botany, New
York Botanical Garden. 
more prominent conspicuous glands at the junction of the lamina and the petiole of the leaves; in $C$. williamsii the leaves are $9-18 \mathrm{~cm}$. long, and $3-5.5 \mathrm{~cm}$. broad, and have $12-15$ pairs of secondary veins. $C$. marlenei is also rather similar to $C$. glabra Prance, but it is not so closely related, differing in the unbranched racemose inflorescence, the much smaller leaves, the very sparse but definite pubescence of the exterior of the flowers, and in the glands at the lamina base.

$C$. marlenei is named after the collector, Marlene Freitas da Silva, who has collected many interesting plants from the Manaus-Porto Velho Highway, and who is contributing much to Amazonian Botany, as the curator of the Manaus Herbarium.

It is interesting that each additional contribution to the Chrysobalanaceae so far has included a new species of Couepia, C. glabra in Prance 1973, and C. dolichopoda in Prance 1974. This indicates that Couepia is still one of the lesser known American genera of the family. C. marlenei keys out to $C$. williamsii in the key in Prance 1972. It can be differentiated, however, by the characteristics given above.

2. Licania octandra (Hoffmpp. ex Roem. \& Schult.) Kuntze subsp. grandifolia Prance, subsp. nov. Ab subsp. octandra et subsp. pallida foliis grandioribus, $14-29 \mathrm{~cm}$. longis, $4.5-7 \mathrm{~cm}$ latis cum acuminibus $12-28 \mathrm{~mm}$ longis differt.

TYPE - E. Lleras, W. C. Steward, J. C. Ongley et al P17270, Brasil, Amazonas: Rio Javari, behind Estirão de Equador, flowering August 1973. (INPA holotype; NY isotype).

\section{ADDITIONAL MATERIAL}

Colombia. Amazonas: Río Loreto-Yacú, L. Glenbowski 206 sterile (NY).

This subspecies is conspicuously different from the other two by its much larger leaves. It may, in fact be a separate species, but I hesitate to describe a new species in this complex based on so little material. Its relationship is certainly with $L$. octandra and this new subspecies represents the western limit of the species, subsp. octandra belonging to the Guianas, eastern Brazilian Amazonia and Central Brazil, and subsp. pallida distributed in Central and western Brazilian Amazonia and extending into Loreto, Peru, thus being sympatric with the new less widely distributed subspecies grandifolia.

\section{Exellodendron gracile Kuhlmann.}

This species was known only from the type gathering at the time of my monograph. Recently it has been collected from the same region, the State of Espírito Santo, Brazil.

Brasil. Espírito Santo: Reserva Florestal Linhares, próximo Estrada 161 talhão 605, árvore de 34 metros de altura, Mata de tabuleiro, J. Spada 151 com flores em 22/1/1973 (INPA, RB162365). Nome vulgar: "Guaiti-mirim".

4. Hirtella lemsii L. O. Williams \& France

A second collection of this species described in Prarice (1972) has now been made, also in Costa Rica.

Costa Rica. Puerto Viejo, Finca la Selva, G. W. Frankie 398c, flowering September 17, 1969.

\section{Licania affinis Fritsch}

In my monograph this species was cited as being distributed in the Guianas, and extending eastwards into eastern Pará, Brazil. Recently three collections of this species have been made from Panama, thus its known geographical range has been greatly extended. $L$. affinis has not been collected in Colombia and Venezuela, and therefore appears to have a disjunct distribution, jumping from Panama to Guyana, a distribution pattern which is also known in other species, and which probably reflects the climatic changes of the past. The Panamanian material is all from the high forest of the Santa Rita Ridge, an area with forest which is rather similar to the area in the Guianas where this species was previously collected. 

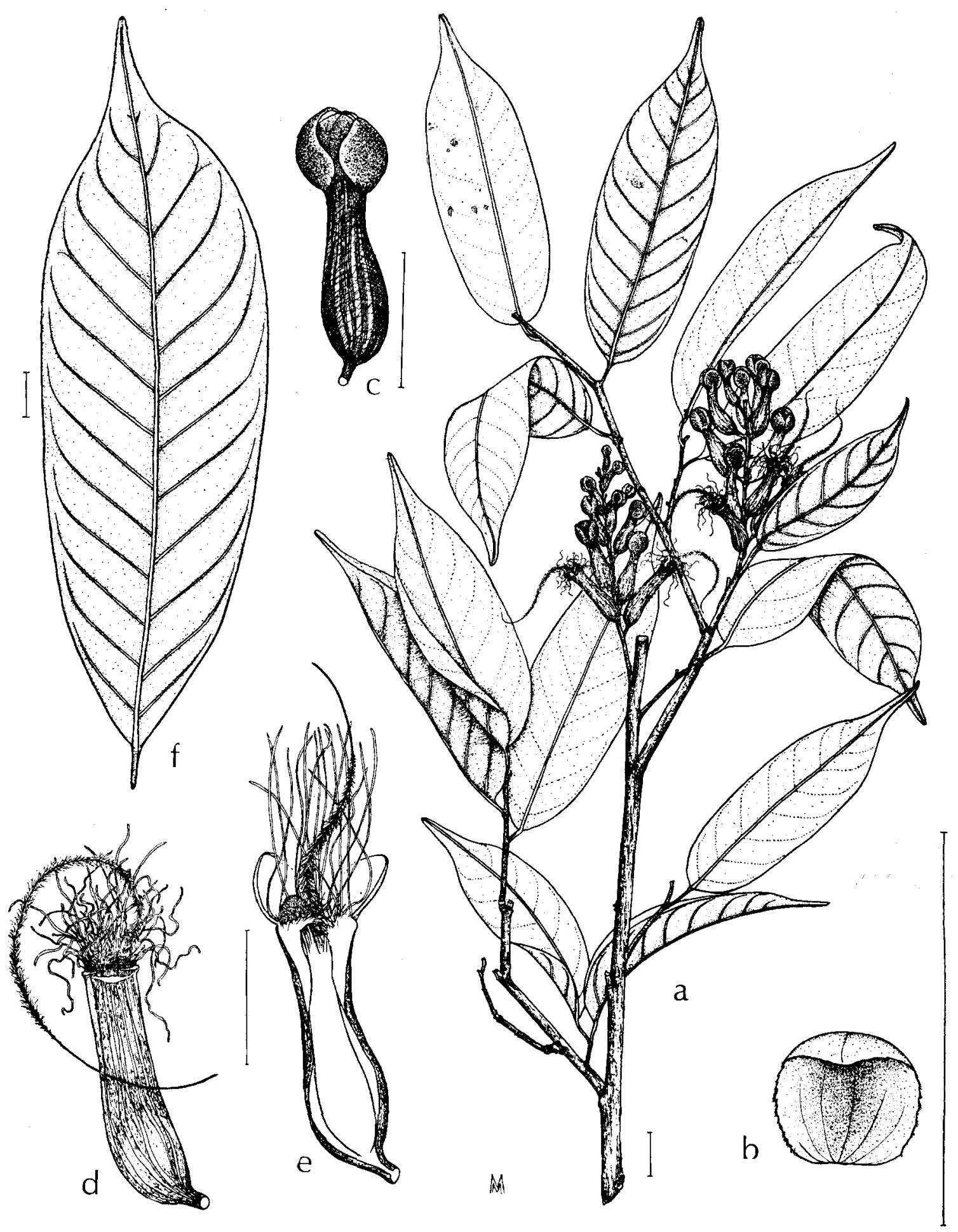

Fig. 1-a-e, Couepia marlenei (Marlene da Silva 822). a, habit; b, petal; c, flower bud; d, flower with perianth removed; e, flower section. f, Couepia williamsii (Tessmann 5382), leaf at same scale as C. marlenei showing difference in size. (All scales marked represent $1 \mathrm{~cm}$. in length.) 
Panama - Colon: Santa Rita Ridge, A. Gomez-Pompa, H. Quero y J. González 3347 fl. (MEXU), 3354 fl. (MEXU); E. Lao, L. Holdridge \& Gentry $10 \mathrm{fr}$. (MO, NY).

Dr. A. Gentry (verbal communication) has pointed out to me some other examples of similar distribution of species and between closely related species for example: Aspidospermum macrospermum Woodson (Apocynaceae) has a similar distribution and Tabebuia striata Gentry (Bignoniaceae) of Panamá is most closely related to $T$. stenocalyx Sprague \& Riley.

\section{Licania retifolia Blake}

This is another species which was known only form the type collection at the time of my monograph. I have now seen two further collections also from the State of Guerrero, Mexico, which confirm that it is a very distinct species, easily distinguishable form other species of the subspecies Moquilea.

Mexico - Guerrero: Rincón viejo, H. Kruse $261 \mathrm{fl}$. (ENCB), $1256 \mathrm{fl}$. (ENCB).

\section{Parinari occidentalis Prance}

This species was described in Prance (1972), from material collected in Bolivia and in the State of Acre, Brazil. A new collection has recently been made from Amazonas, Brazil, considerably extending northwards the known range.
Brasil - Amazonas: Rio Javari, Palmeiras Army Post, E. Lleras, W. C. Steward, J. Ongley et al. P17196 (INPA, NY).

\section{ACKNOWLEDGEMENT}

This work was carried out with the support of the National Science Foundation Grant GB-32575X, which is gratefully acknowledged.

\section{SƯMÁRIo}

Estudo adicional sobre a família das Angiospermas, Chrysobalanaceae. Após a última publicação sobre a familia, aproximadamente quinhentas amostras novas foram estudadas. As amostras mais interessantes sāo citadas aqui, incluindo a descrição da nova espécie Couepia marlenei Prance, e uma nova subespécie Licania octandra (Hoffmgg. Roem. \& Schult.) Kuntze, subsp. grandifolia Prance. São também citadas algumas coletas de cinco outras espécies. A espécie Licania affinis Fritsch, muito comum nas Guianas e em Pará agora foi encontrada no Panamá, mostrando uma distribuição disjunta.

\section{REFERENCES CITED}

Prance, G, T.

1972 - Chrysobalanaceae, Flora Neotropica 9, $410 \mathrm{p}$.

1973 - New and Interesting Chrysobalanaceae from Amazonia, Acta Amazonica 2(1) : 7-16.

1974 - A new Peruvian species of Chiropterophilcus Couepia (Chrysobalanaceae). Brittonia. 26 (in press). 